\title{
BIOMATERIALS IN ENDOPROSTHETICS
}

\section{BIOMATERIALI V ENDOPROTETIKI}

\author{
Drago Dolinar ${ }^{1}$, Matevž Gorenšek ${ }^{2}$, Monika Jenko ${ }^{3}$, Matjaž Godec ${ }^{3}$, Barbara Šetina Batič ${ }^{3}$, \\ Črtomir Donik ${ }^{3}$, Aleksandra Kocijan ${ }^{3}$, Mojca Debeljak ${ }^{4}$, Boštjan Kocjančič ${ }^{1}$ \\ ${ }^{1}$ Department of Orthopaedic Surgery, University Medical Centre Ljubljana, Zaloška 9, 1000 Ljubljana, Slovenia, \\ ${ }^{2}$ MD-Medicine, Sanatorium Ljubljana, Bohoričeva 8, 1000 Ljubljana, Slovenia, \\ ${ }^{3}$ Institute of Metals and Technology, Lepi pot 11, 1000 Ljubljana, Slovenia \\ ${ }^{4}$ University Rehabilitation Institute, Republic of Slovenia, Linhartova 51, 1000 Ljubljana, Slovenia \\ monika.jenko@imt.si
}

Prejem rokopisa - received: 2017-11-20; sprejem za objavo - accepted for publication: 2017-12-22

doi:10.17222/mit.2017.196

The use of endoprosthetics for hip- and knee-joint replacements is currently the most common and successful method in orthopaedic surgery to treat degenerative joint disease, for relieving pain and for correcting deformities. Cobalt-chromiummolybdenum alloys, titanium alloys, trabecular tantalum, Biolox ceramics, UHMWPE polyethylene and PMMA bone cement are the most common biomaterials used in endoprosthetics. The published results of long-term investigations demonstrate excellent clinical results for at least 15 years after TJR implantation surgeries. Using new, improved surgical methods as well as new, improved implants made of advanced biomaterials, better clinical results are expected. While these surgeries have positive outcomes, approximately $10 \%$ of implants fail prematurely. Aseptic loosening and periprosthetic joint infection are the main causes of failure for joint arthroplasty. The Orthopedic Clinic Ljubljana performs between 80 and 100 revision surgeries of knee and hip endoprostheses per year. The most common causes for revision surgeries are aseptic loosening and implant infection For all treated patients the clinical course of treatment including X-ray documentation is precisely followed. The retrieved endoprostheses are sent for bacteriological analysis, and afterwards are preserved for further investigations. The surface and microstructure analyses of retrieved hip and knee endoprostheses were performed in cooperation with IMT Ljubljana using advanced analytical and integrated electron spectroscopy techniques. Two new and two retrieved endoprostheses were studied The surface chemistry and microstructures of both the new and used titanium alloys and CoCrMo alloys used for hip and knee endoprostheses were determined using SEM (morphology), EBSD (phase analysis), and AES and XPS (surface chemistry). The SEM SE and BE images revealed their microstructures, while the EBSD provided the phases of the materials. During the production of hip and knee endoprostheses, these materials are subject to severe thermomechanical treatments and physicochemical processes that are decisive for CoCrMo alloys. The AES and XPS results showed that thin oxide films on a) Ti6Al4V are a mixture of primarily $\mathrm{TiO}_{2}$ with a small amount of $\mathrm{Al}_{2} \mathrm{O}_{3}$, while the $\mathrm{V}$ is depleted, b) Ti6Al7Nb is a mixture of primarily $\mathrm{TiO}_{2}$ with a small amount of $\mathrm{Al}_{2} \mathrm{O}_{3}$ and $\mathrm{Nb}_{2} \mathrm{O}_{5}$, and c) the CoCrMo alloy is a mixture of primarily $\mathrm{Cr}_{2} \mathrm{O}_{3}$ with small amounts of Co and Mo oxides.

Keywords: biomaterials, knee and hip endoprosthesis, microstructure, surface chemistry, SEM, EDS, EBSD, AES and XPS

Endoprotetika kolčnega in kolenskega sklepa (TEP) je dandanes uveljavljena in uspešna metoda zdravljenja napredovanih degenerativnih sprememb teh sklepov za lajšanje bolečin in za odpravljanje deformacij. Prav v zadnjih letih se uveljavljajo nove operativne metode, izboljšani implantati iz novejših, vse boljših materialov. Hitrejša je tudi pooperativna rehabilitacija teh bolnikov. Najpogostejši biomateriali, ki se uporabljajo za izdelavo kolčnih in kolenskih endoprotez, so titanove zlitine, kobalt-krom-molibdenove zlitine, trabekularni tantal, keramika in UHMWPE polietilen in PMMA kostni cement. Kljub dobrim fizikalnim lastnostim, se pri uporabi teh materialov pojavljajo težave, povezane z obrabo in korozijo, kar dolgoročno privede do omajanja vgrajenih implantatov. Objavljeni rezultati dolgoročnih preiskav kažejo odlične klinične rezultate najmanj 15 let po operacijah TEP. Uporaba novih, izboljšanih kirurških metod in novih, izboljšanih vsadkov iz naprednih biomaterialov, nakazuje boljše klinične rezultate. Kljub odličnim rezultatom omenjenih operacij, približno $10 \%$ implantatov prezgodaj odpove. Aseptično omajanje in periprostetična okužba sta najpogostejša vzroka za odpoved implantanta. Ortopedska klinika Ljubljana opravi od 80 do 100 revizijskih operacij endoprotez kolena in kolka letno. Najpogostejši vzroki za revizijske operacije so aseptično omajanje in okužba vsadkov. Za vse zdravljene bolnike je natančno upoštevan klinični protokol zdravljenja, vključno z rentgensko dokumentacijo. Odstranjene endoproteze se pošljejo na bakteriološko analizo, potem pa se ohranijo za nadaljnje preiskave. Analize površin in mikrostrukture endoprotez kolka in kolena so bile izvedene v sodelovanju z Inštitutom za kovinske materiale in tehnologije (IMT) Ljubljana z naprednimi integriranimi analitskimi tehnikami elektronske spektroskopije. Studirali smo dve novi in dve uporabljeni endoprotezi. Površinsko kemijo in mikrostrukturo novih in uporabljenih titanovih zlitin in CoCrMo zlitin, ki se uporabljajo za endoproteze kolka in kolena, smo določili z uporabo SEM (morfologija), EBSD (fazna analiza) ter AES in XPS (površinska analiza). Slike SEM, SE in BE prikazujejo mikrostrukturo, medtem ko EBSD analizo faz materialov. Med proizvodnjo endoprotez kolka in kolena so ti materiali izpostavljeni termomehanskim obremenitvam in fizikalno-kemijskim postopkom, ki so odločilni za kakovost CoCrMo zlitin. Rezultati AES in XPS so pokazali, da so tanki oksidni filmi na: a) Ti6Al4V zlitini predvsem $\mathrm{TiO}_{2}$ z majhno količino $\mathrm{Al}_{2} \mathrm{O}_{3}$, b) $\mathrm{Ti6} \mathrm{Al} 7 \mathrm{Nb}$ zlitini je predvsem $\mathrm{TiO}_{2} \mathrm{z}$ majhno količino $\mathrm{Al}_{2} \mathrm{O}_{3}$ in $\mathrm{Nb}_{2} \mathrm{O}_{5}$ in c) na zlitini CoCrMo je predvsem $\mathrm{Cr}_{2} \mathrm{O}_{3}$ z majhnimi količinami Co in Mo oksidov.

Ključne besede: biomateriali, kolenske in kolenčne endoproteze, mikrostruktura, faze, površinska analiza, SEM, EDS, EBSD, AES in XPS 


\section{INTRODUCTION}

The endoprosthetics of hip and knee joints (TJR) is nowadays the established method for treating advanced degenerative changes in these joints and one of the most successful and often performed orthopaedic procedures. Annually, more than a million hip endoprostheses and nearly two million knee endoprostheses are implanted worldwide. ${ }^{1}$ Indications in patients with hip or knee pain are varied, and the insertion of a TJR, as a rule, eliminates the pain in these patients, improves the mobility and the quality of life.

The most common biomaterials used to make hip and knee endoprostheses are titanium alloys, cobalt-chromium-molybdenum alloys, trabecular tantalum, ceramics and polymers. In spite of the good physical properties, problems associated with wear and corrosion occur in the use of these materials, which in the long run leads to the instability of the embedded implants. Recently, tribological investigations of orthopaedic implants (problems of lubrication, friction and wear among individual parts of embedded endoprostheses) and related research on the influence of individual wear and corrosion products on the human tissue have been established, which will enable us in the future to further clarify the causes of premature failure of orthopaedic implants.

According to the latest literature related to the problem of the premature failure of orthopaedic implanted hip and knee endoprostheses, there are two main causes that are responsible for this problem. These are aseptic loosening and infections. ${ }^{1-3}$ Aseptic loosening of the endoprosthesis is the loss of endoprosthesis in its bone bed. The most common result is the wear of endoprostheses and consequent osteolysis. Other etiologies represent poor initial implant stability, poor implantation (inadequate geometry and surface treatment of the implant) and consequently unsuccessful osseointegration of the implant. Infection of the hip or knee endoprosthesis is a serious complication; the most common cause is infection by staphylococcus aureus. Such infections require a long-term antibiotic treatment, often the removal or replacement of the endoprosthesis, a prolonged hospital stay, and longer and more demanding rehabilitation, all of which greatly increases the cost of the treatment.

The latest studies show a potential link between the "aseptic-non-bacterial" implantation of the implant and latent implant infection. They found that the diagnosis was wrong, and the latent "low-grade infection" was crucial for the premature loosening of the implant. There are studies which show that for the implants a free surface competition is in progress, and if the host cells first occupy the surface of the implant, a strong integration of the tissue and the formation of a barrier occurs to prevent the adhesion and colonization of microbes and the formation of a biofilm. ${ }^{4}$ A strong osseointegration and the prevention of infection are both criteria necessary for the success and long-term use of the implant, which should be taken into account in the design of the implants. $^{2}$

Recent research and possible improvements to orthopaedic implants are being carried out, in particular, in the direction of improving the surface treatment of implants, which would allow for faster and better osteointegration of the implant, while also preventing the possible surface colonization of bacteria and the formation of a bacterial biofilm on the implant. ${ }^{2}$

In recent years, new surgical methods have also been applied, and implants from novel, better materials have been improved. The postoperative rehabilitation of these patients is also faster.

This paper highlights the basic novelties in this field of orthopaedic surgery and preliminary results of surface chemistry and microstructure analysis of retrieved hip and knee endoprostheses.
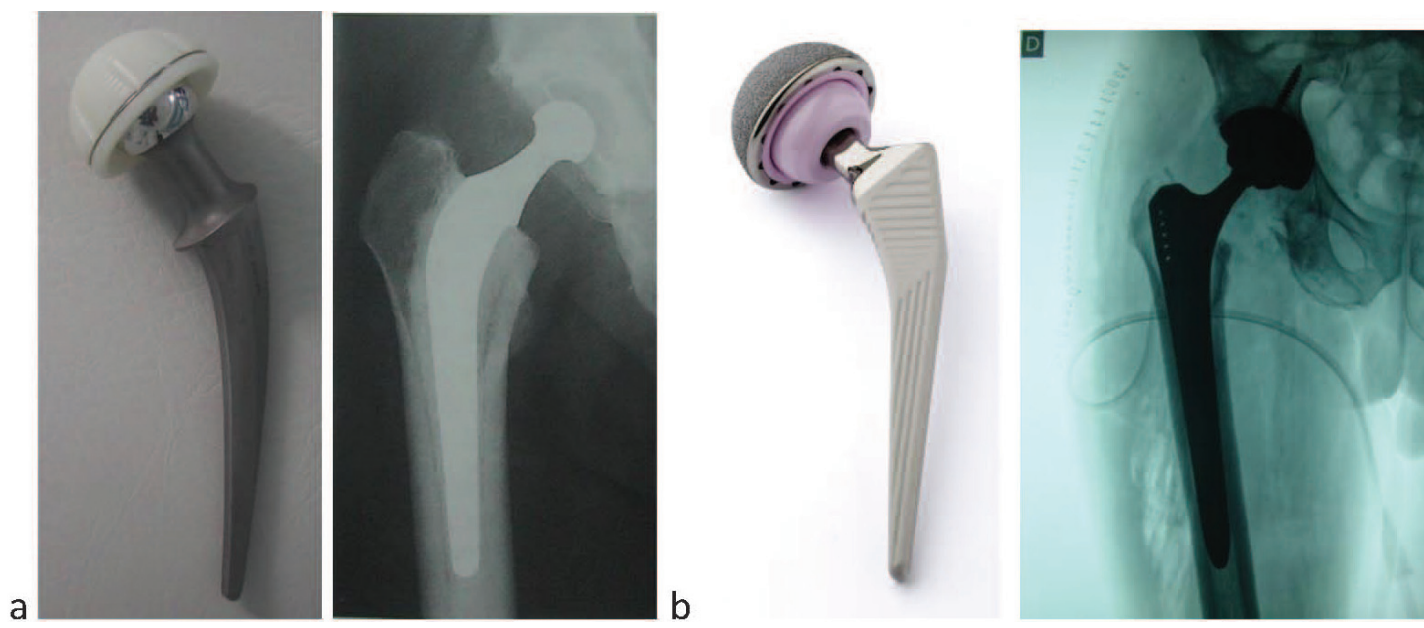

Figure 1: a) cemented total hip arthroplasty (THA), b) uncemented THA. Currently, THA usually uses an uncemented titanium (TiAl6V4, TiAl6Nb7) or cemented cobalt-chromium alloy (CoCr28Mo6) femoral stem (fixed into place for uncemented or cemented with PMMA) and a modular cobalt-chrome alloy or ceramic head. The head articulates on a ceramic or ultra-high molecular weight polyethylene (UHMWPE) acetabular cup fitted into a titanium or cobalt-chromium cup liner that is press fitted or screwed into place or a complete UHMWPE cemented 


\section{NOVELTIES AND IMPROVEMENTS IN HIP ENDOPROSTHETICS}

From the starting idea, at the beginning of the last century, several decades have passed since the artificial hip joint was developed. In the late 50s, Sir John Charnley introduced the use of bone cement to strengthen the components of hip endoprosthesis into the bone, developed the shape, and laid out the biomechanical principles of hip endoprosthetics.

The modern low-friction hip arthroplasty era began in the early 1970s with the hard-on-soft bearing concept where polyethylene was used in the cup, stainless steel in the femoral head and stem and poly-methyl-methacrylate (PMMA) as bone cement. ${ }^{5,6}$ The total hip arthroplasty (THA) developed by Charnley has been successful ever since, with $77 \%$ to $81 \%$ survivorship after a 25 -year follow-up reported in the first-generation results of his low-friction arthroplasty with the revision of any component as the endpoint. Long-term survival in more than $90 \%$ of patients over 60 years of age has been associated with Charnley's THA. ${ }^{7,8}$

By implanting artificial hip joints, some perioperative, short-term and long-term complications are also encountered. Among the most common perioperative complications are hematoma, seroma, pulmonary embolism, and paresis of the femoral or sciatic nerve. The most common short-term complications are infection and dislocation, and in the long-term, it is particularly important to mention the aseptic loosening of the artificial hip joint, which requires the replacement of one or both parts of the endoprosthesis. Decades have passed before scientists have at least partially managed to resolve the cause of the aseptic loosening of endoprostheses. The isolation and identification of micron and submicron particles from the tissue at the prostheses, their biological activity, the formation of macrophages, their activation, the release of cytokines, etc., were discoveries that led to the finding that the process of loosening is a very complex one. Today, it is known that most of the particles found in the tissue in the vicinity of the hip endoprosthesis are polyethylene particles, hence the "disease of polyethylene particles". Polyethylene acetabular cups are the main cause of the aseptic loosening of an artificial hip joint. ${ }^{1}$

Due to the known possible complications in the replacement of hip joints with artificial ones, new minimally invasive operative methods are being introduced, as well as ever-better materials (both in cemented and non-cemented hip endoprostheses). These improvements allow the faster recovery of patients to live a normal life, as well as prolongation of the expected lifespan of hip endoprostheses (Figure 1). Today, we estimate that the normal life expectancy of modern hip endoprostheses is in the range from 20 years to 25 years.

\subsection{Novel materials in modern endoprosthetics of the hip joint}

Due to the polyethylene particles disease, which is the main cause of aseptic loosening of hip endoprostheses, recently we have used newer polyethylene acetabular cups or polyethylene acetabular inserts from the mechanically resistant, highly cross-linked polyethylene-HXLPE. Cross-linking can be accomplished using gamma radiation. A subsequent annealing stage is performed in order to reduce the free radicals that are produced by the radiation (first-generation HXLPE). Test data from contemporary hip simulators have shown an $80 \%$ to $90 \%$ reduction in wear with highly cross-linked polyethylenes. ${ }^{1}$ One promising approach to improving oxidation resistance is the addition of antioxidants such as $\alpha$-tocopherol (or vitamin E) to the material, thereby preventing oxidation of the polymer, while allowing for cross-linking or sterilizing irradiation in the absence of a post-irradiation thermal stabilization (second-generation HXLPE). Vitamin E (VE) is an effective biological antioxidant, helping to prevent the oxidative degradation of cell-membrane phospholipids. When added to UHMWPE, VE performs a similar role, helping to prevent oxidation of polyethylene chains. ${ }^{9}$

Modern methods of cementing have increased the quality of cement endoprostheses (vacuum mixing of cement, pulse cleansing of the femoral channel, retrograde cement introduction into the femoral channel, low viscosity of cement, use of cement with antibiotics). ${ }^{10}$

In modern orthopaedics, cement-free hip endoprostheses made of titanium are increasingly being used. As a biocompatible material, titanium has been known for its excellent osteointegrative capacity. The use of titanium-based materials reduces the stress-shielding effect and debris generation. This is because its modulus of elasticity is closer to cortical bone than that of Co-Cr-Mo alloys. Ti-based implants can be inserted without bone cement, which is typically used with Co-Cr-Mo femoral stems to improve the stress distribution to the bone. The drawback of titanium alloys relates to their softness compared with Co-Cr-Mo alloys and also to their relatively poor wear and frictional properties. For this reason, titanium alloys are rarely used when hardness or wear resistance is considered to be the optimal property.

A non-cemented femoral component is an excellent choice for young patients as well as for patients with good bone density (especially for those with a thick femoral cortex and a smaller diameter of the femoral canal). However, it is sometimes difficult to obtain good initial stability with a cement-free implant in patients with a broad femoral channel and porous bone. Therefore, the cement implant is an appropriate choice in elderly, physically less active patients with a poor bone structure (thin cortical bone and broad femoral canal). ${ }^{1}$ Cement-free implants are usually coated with a porous material to increase the area for bone ingrowth. Moreover, the rough surface allows for greater initial implant 
stability, which is crucial for the long-term success of the endoprostheses. The porous coating can be limited to the proximal part of the femoral component, or it may take place over the entire length of the implant. This varies according to the philosophy of designing the component itself. Proximal coated implants are fixed in a metaphysis or metadiaphysis. Widely coated implants are fixed distally in the femoral diaphysis. Some non-cemented prostheses are also coated with hydroxyapatite, which promotes bone formation and allows for an even faster ingrowth of the endoprosthesis.

We use either self-contained cement-less acetabular cups, and recently, especially press-fit acetabular cups, which are pressed into a ready-made acetabular bed or "highly cross-linked" polyethylene acetabular inserts, especially in younger patients, and more and more often ceramic acetabular inserts. Until recently, we have avoided ceramic hip endoprostheses (ceramic headceramic acetabular insert) due to the brittleness of the ceramics, and the complications because of this.

For novel, more robust and mechanically resistant ceramics (Biolox delta ceramics - an alumina matrix composite made up of $82 \%$ alumina, $17 \%$ zirconia, $0.6 \%$ strontium oxide and $0.3 \%$ chromium oxide) these problems no longer exist, providing both endoprosthesis components are correctly mounted. ${ }^{10,11}$ Due to the mechanical strength of ceramics, the wear of these endoprostheses is minimal.

In recent years tantalum implants have been used in adult hip and knee surgery. Tantalum is an elemental metal with great characteristics for biocompatibility, corrosion resistance, and a porous geometry. Tantalum, marked as Trabecular Metal, has a uniform and continuous structure that allows for greater strength, lower stiffness, higher volumetric porosity, and a higher coefficient of friction compared to other porous metals. The porous structure has higher porosity than other materials used in orthopaedic implants like sintered beads (30-35\%) and fibre metal $(40-50 \%)^{8}$, providing a great increase in elasticity and making porous tantalum mechanical properties very close to those of the subchondral bone. The great number of pores and their dimensions positively affect the stability of the implant, increasing the friction coefficient, up to even three times higher than sintered bead materials. ${ }^{12}$ In the case of marked bone loss, trabecular implants have been used to supplement the fixation in total hip and knee arthroplasty. ${ }^{13}$

In selected revision cases with extensive bone deficiencies of the femur or tibia, tumour cases or difficult cases after the treatment of periprosthetic joint infection, silver-coated mega implants are used. The infection rate of modular mega-endoprostheses is stated in the literature as 4-36\%. Various in-vitro studies have shown that silver coatings effectively inhibit or even prevent the formation of biofilms on the metal surfaces of different bacteria. Several clinical studies have confirmed the positive effects of silver coatings in preventing infections in endoprostheses. ${ }^{14}$

For all hip implants, the femoral head must match the acetabular insert. The endoprosthesis can be metallic or ceramic. The metal heads are made of cobalt-chrome alloys. Different sizes from $22 \mathrm{~mm}$ to $38 \mathrm{~mm}$ are available (sometimes even more). The size of the head influences the motion, stability and tendency to wear. With the enlargement of the head, the range of motion increases and the tendency for laxation is lowered, but at the same time the wear of the material and the formation of the wear particles increases. With improved materials and, consequently, smaller wear of the contact surfaces (ceramic head in combination with a ceramic or HXLPE acetabular insert), more and more surgeons select for the use of a larger femoral head (32 $\mathrm{mm}$ and $36 \mathrm{~mm}$ ).

From the biotribological point of view the increased head size coupled with decreased clearance has been proved to improve lubrication, as happens for both metal-to-metal (MoM) large head and ceramics-to-ceramics (CoC) implants, which can operate under a fluid-film lubrication regime (favourable regarding the wear of the articulating surfaces). The best lubrication behaviour is estimated for $\mathrm{CoC}$ implants: their high surface finishing (i.e., very low roughness) balances the low film thickness, guaranteeing a fluid-film regime. It is worth noting that the clearance must be dimensioned properly, avoiding both large values, which would lead to the boundary regime and low values, which might cause edge contact and thus lubricant starvation (unfavourable conditions regarding wear). Conversely, larger head sizes increase the frictional torque, consequently the stresses are larger on tapers and bone-implant interfaces (unfavourable regarding implant survival) and in metal-to-polymer (MoP) or (ceramics-to-polymer) $\mathrm{CoP}$ bearings more polyethylene wear is due to a longer sliding distance per step. ${ }^{15}$

Several years ago metallic contact surfaces were reintroduced in the endoprosthetics of the hip joint, using modern metal implants. Such component contacts have proved to exhibit reduced wear compared to the standard contact surface where the metal head slides on polyethylene. The most popular was primarily arterial arthroplasty, which is the biomechanical best approximation to the normal hip condition. Subsequent studies have shown that the metal-to-metal contact surface did not yield clinical advantages, but caused an even greater number of revisions. ${ }^{16}$ For these patients strongly elevated levels of cobalt and chromium ions in the serum, erythrocytes, and urine were registered. This is associated with the potential for an increased incidence of certain cancers. An even greater problem is the local release of metal particles and the vigorous response of the body. Pseudotumours are formed, and loosenings of endoprostheses are more frequent. The use of prostheses with a metalcontact surface is therefore being abandoned. 


\subsection{Minimally invasive surgical methods for replacing the hip joint}

In recent years, when replacing a hip joint with an artificial one, we often decide for a minimally invasive approach that reduces blood loss during surgery and enables faster and less painful rehabilitation of the patient. Until recently, the operations were carried out in such a way that the individual circumferential muscles were separated by means of cutting or releasing the increments of the individual muscles to the bone. With the newer approach, the muscles are only released, which is significantly more favourable, since the surrounding muscles are not damaged. Also, the skin cuts are shorter; therefore, a specially adapted instrument is used, which enables normal and precise replacement of the hip joint. A patient can step on the foot and load it to pain the first day after the surgery and after the fifth to the seventh day after the surgery, the patient is released from the hospital and can return to normal life much more quickly than before.

\subsection{Novelties in the knee joint endoprosthetics}

The modern era of the replacement of defective knee joint starts in 1974, when Insall designed the so-called total condylar prosthesis with a recess to contact with a knee pad. To replace the tibial part of the joint, a polyethylene insert attached to the metal plate was used. Various improvements followed, and basically such prostheses are still used today (Figure 2). ${ }^{1}$

The goal of inserting knee endoprosthesis is to achieve a painless, stable and easily-moving knee joint, thus improving the quality of life for patients with worn-out knee joints.

The knee is not a simple hinged joint, but has a complex mobility around and along all three axes, which are even changing in the course of movement. This means that the basic motion, bending-out, does not take place around the fixed axes, but around the constantly changing rotation centres. In addition, the movement is combined with rotations and slips between the femoral and tibial condyles. Because of this, biomechanically, a knee endoprosthesis is much more complicated than a hip. The ideal knee endoprosthesis should provide normal movements, to a normal extent in all three axes. Patients should be aware that the complexity of the functioning of a normal knee joint, despite modern techniques and implants, cannot be fully achieved.

Cemented endoprostheses provide very good longterm clinical results and therefore constitute a "gold standard". Long-term results of non-cemented knee endoprostheses are significantly worse, according to the data of internationally published national registries, mainly due to the more frequent loosening of the tibial part of endoprosthesis. Recent advanced models of noncemented knee endoprostheses (modern porous coatings, the use of hydroxyapatite and, above all, the use of trabecular metals), show encouraging, medium-term, clinical results that are even better than cemented-type knee endoprostheses. ${ }^{17}$

In unilateral wear of the knee joint unicondylar knee endoprostheses are used. In severe knee joint deformities with markedly ligamental instability or major bone defects, a hinge-type knee prosthesis is used with cemented or non-cemented femoral and tibial intramedullary extensions, which improve the stability of knee endoprostheses.

Recently, we have learned that the lifespan of knee endoprostheses, considering the correct biomechanical incorporation and according to the results from the literature, is up to 15 years after installation (in $95 \%$ of cases). ${ }^{1}$ An experienced surgeon will allow for the longer mechanical stability of these endoprostheses by aligning the mechanical axis of the lower limb with the centre of the implant, by aligning the transverse axis of the knee with the base plane and by providing the ligament's
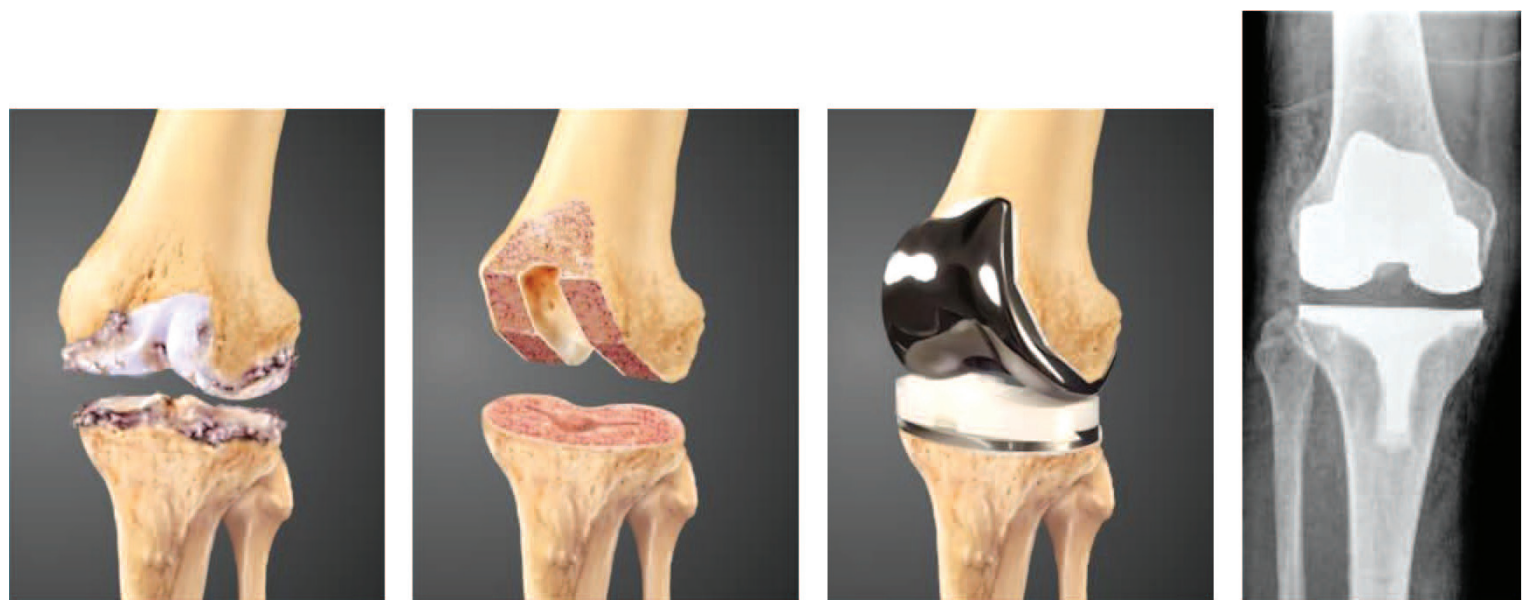

Figure 2: Total knee endoprosthesis is nowadays the most common implant used to replace a defective knee joint. It consists of a metallic femoral part (cobalt-chromium) with a recess forming a contact surface with a knee pad and a polyethylene tibial part with a metal carrier (cobalt-chrome, titanium) and an intramedullary extension that anchors the part into the bone. The femoral and tibial components are usually attached to the bone with bone cement (polymethyl methacrylate) ${ }^{1}$ 
stability and the balance of the knee joint. In recent years, the computerized installation of knee endoprostheses has been progressively implemented. The surgeon is computer-assisted in a more precise biomechanical installation, especially for minimally invasive operative methods, where the knee joint's visibility is worse and therefore the possibility of improper insertion of the knee endoprosthesis becomes greater. Computer-assisted methods are still improving and are not routinely used in clinical practice, mainly due to the longer surgical operating times.

In modern endoprosthetics of the knee joint, we also use novel technologies and materials that are the same as for endoprosthetics of the hip joint (modern metallic femoral part, "highly cross-linked" polyethylene tibial part, improved techniques of positioning and positioning of knee endoprosthesis components). ${ }^{18}$ The use of ceramics is also becoming important. In clinical use, metal femoral components with a ceramic coating (e.g., Oxinium - oxidized zirconium is a metallic alloy with a ceramic surface that provides wear resistance without brittleness) are introduced. With advanced models of primary knee endoprostheses, we approach the ideal implant model, which must ensure a normal or almost normal range of motion in all three axes (i.e., a freegliding endoprosthesis), and the extent of movement should be limited by soft tissues, in particular the ligaments.

\section{PRELIMINARY RESULTS OF SURFACE CHEMISTRY AND MICROSTRUCTURE ANALYSES OF RETRIEVED HIP AND KNEE ENDOPROSTHESES}

Recent investigations of metallic biomaterials involved corrosion, bio-tribocorrosion, taper corrosion, wear, metalosis-cobaltosis-Co metal ions in patients' blood and urine MoM. In addition there are the object studies of the influence of acetabular diameter on hip osseointegration, multifunctional coatings of hip endoprostheses and the prevention of biofilm formation on the implant surfaces. Later studies showed the competition for a free implant surface of host cells and bacteria (staphylococcus aureus). If the host cells first occupy the surface of the implant, a strong integration of the tissue and the formation of a barrier occurs, which prevents the adhesion and colonization of bacteria and the formation of biofilm. ${ }^{2}$

Our key contribution is a detailed surface characterization, required for a better understanding and exploitation of the surface properties. Microstructure is a neglected factor in implant design and for that reason a detailed microstructure characterization is required to determine the role of prematurely failed implants that determine the biological responses such as the composition and structure of the surface oxide film, the surface contamination and the surface topography. ${ }^{19}$

\subsection{Materials and methods}

Implants, retrieved and new, listed in Table 1, were provided by the Orthopeadic Clinic of the University Medical centre Ljubljana. We studied CoCrMo alloys, Ti6Al4V and Ti6Al7Nb alloys.

The samples were cut from new and retrieved endoprostheses using a water jet. The samples were prepared by standard metallographic procedures, using Struers devices. All the samples for the surface-chemistry analyses had highly polished surfaces.

We have used XRF, ICP-OES for the chemical analysis, SEM for the visualization, SEM/EDS for the chemical analysis, SEM/EBSD for the phase analysis and the grain orientation, AES for the surface analysis.

\section{RESULTS}

\subsection{Chemical analysis}

X-ray fluorescence (XRF) and inductively coupled plasma optical emission spectrophotometry (ICP-OES) analyses of the implant biomaterials showed that the chemical compositions of the alloys are within the requirements of ASTM F 1295 (Ti6Al7Nb alloy); ASTM F136 (Ti6Al4V alloy), and ASTM F75 (CoCrMo alloy).

\subsection{SEM and EBSD analyses of Ti6Al4V, Ti6Al7Nb and CoCrMo alloys}

The microstructures of the samples were investigated using a JEOL JSM 6500F field-emission scanning electron microscope (SEM) equipped with a HKL Nordlys II electron-backscatter diffraction (EBSD) camera using

Table 1: The investigated components of retrieved and new implants

\begin{tabular}{|c|c|c|c|c|}
\hline KNEE /HIP endoprostheses & KNEE EP1 & KNEE EP2 & KNEE EP3 & HIP P1 \\
\hline PRODUCER & Depuy & Depuy & Not known & Smith \& Nephew \\
\hline Served in human & new & 3 month & 22 years & new \\
\hline Femoral component & CoCrMo & CoCrMo & CoCrMo & - \\
\hline Tibial component & Ti6Al4V & Ti6Al4V & Ti6Al4V & - \\
\hline Polyethylene liner & UHMWPE & UHMWPE & UHMWPE & - \\
\hline HIP-stem & - & - & - & Ti6Al7Nb \\
\hline HIP acetabular & - & - & - & Ceramics Biolox delta \\
\hline HIP acetabular polymer cup & - & - & - & UHMWPE \\
\hline HIP acetabular metal cup & - & - & - & $\mathrm{cp} \mathrm{Ti/Al}$ \\
\hline
\end{tabular}



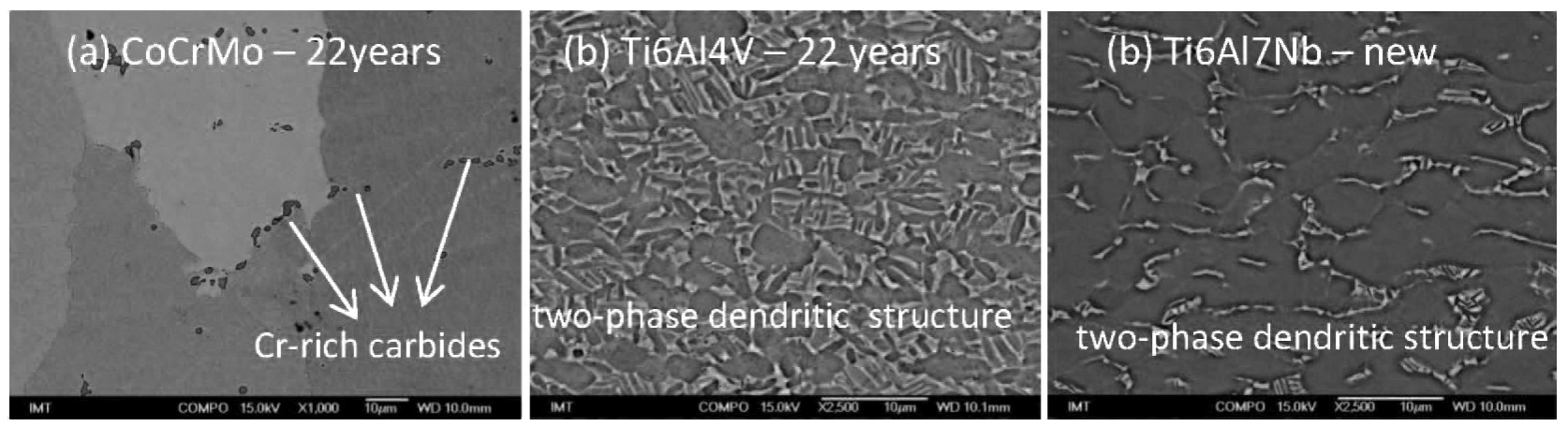

Figure 3: Backscattered-electron (BE) images of clinical implant microstructures, a) CoCrMo alloy (retrieved after 22 years), b) Ti6Al4V alloy (retrieved after 22 years), (c) Ti6Al7Nb alloy (new component)
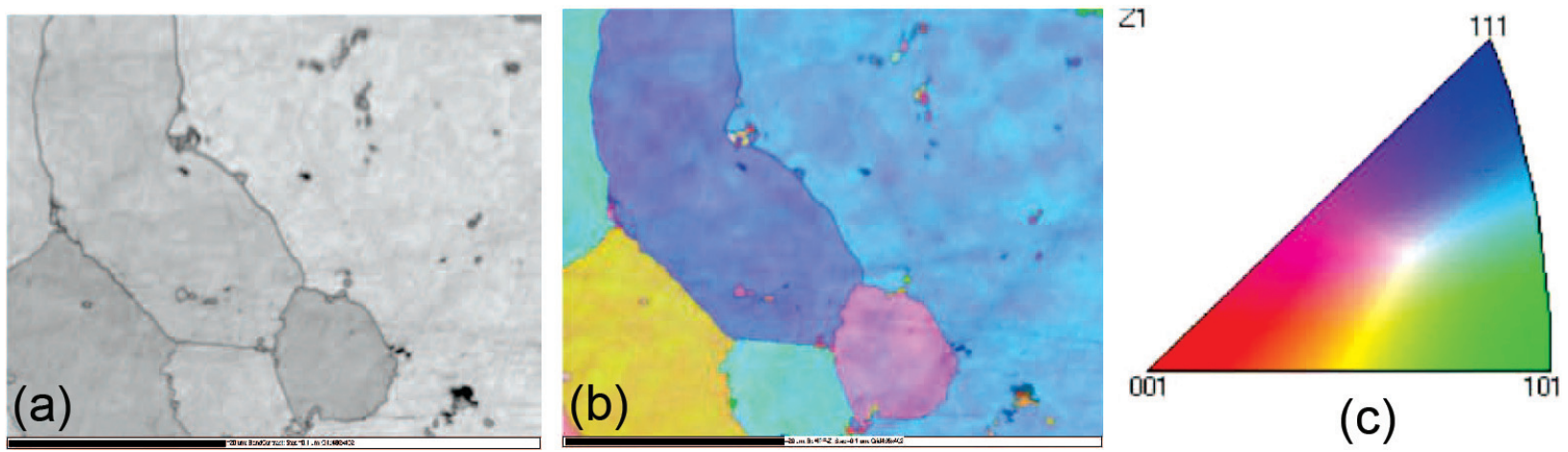

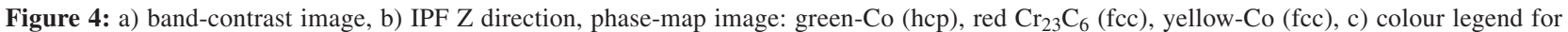
IPF Z colouring

Channel 5 software. Individual diffraction patterns were obtained together with mapping of the area of the interest. The instrument was operated at $15 \mathrm{kV}$ and approximately 2-nA current for the EBSD analysis, with a tilting angle of $70^{\circ}$. The instrument has both secondary-electron (SE) and backscattered-electron (BE) imaging modes for morphological analyses of the samples. For the SE or BE imaging, the instrument was operated with an acceleration of $15 \mathrm{kV}$ at a current of approximately $0.5 \mathrm{nA}$. The vacuum was maintained below $1 \cdot 10^{-6}$ mbar.

Figure 3, backscattered-electron (BE) images, shows the cast microstructure of the CoCrMo alloy with $\mathrm{Cr}$-rich carbides, Ti6Al4V and Ti6Al7Nb alloys a two-phase dendrite structure in a matrix of Ti6Al4V and Ti6Al7Nb, respectively, studied by SEM. The microstructures of the new and retrieved components are very similar, so only representative images of each composition are shown.

EBSD analyses showed that the microstructure of the CoCrMo alloys, the face-centred cubic (fcc) and the hexagonal close-packed (hcp) crystalline structures co-exist. Typically, the (fcc) phase is predominant at room temperature, but the (fcc) to (hcp) transformation could be isothermally or strain induced. The CoCrMo alloys show different hard phases after casting and further heat treatments, such as the $\mathrm{M}_{23} \mathrm{C}_{6}$ type $(\mathrm{M}=\mathrm{Cr}$, $\mathrm{Mo}, \mathrm{Co}), \mathrm{M}_{7} \mathrm{C}_{3}$, and intermetallic phases of Mo-, $\mathrm{Co}-$ and Si-like ( $\sigma$-type) phases, which have the same size as the eutectic carbides. Figure 4 shows in a) band-contrast
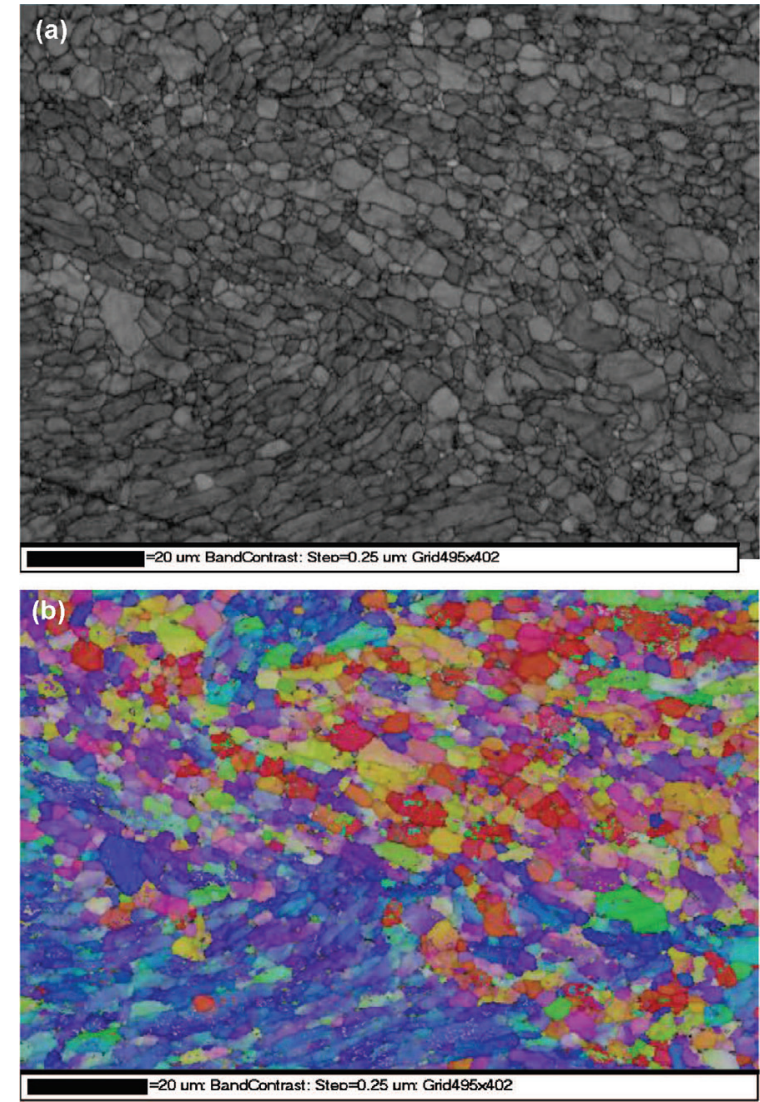

Figure 5: Ti6Al4V EBSD mapping of phases: a) band-contrast image, b) IPF $\mathrm{Z}$ direction 

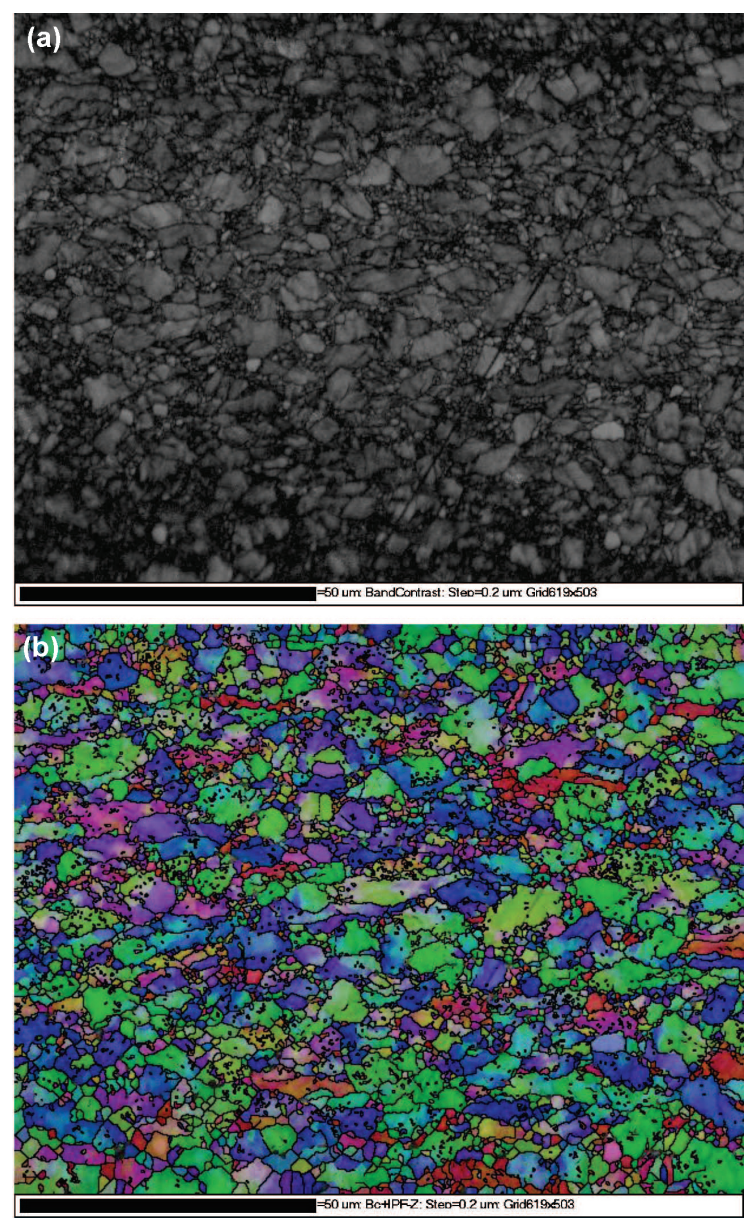

Figure 6: Ti6A17Nb EBSD mapping of phases: a) band-contrast image, b) IPF $\mathrm{Z}$ direction

image, b) IPF $\mathrm{Z}$ direction, phase-map image: green-Co (hcp), red $\mathrm{Cr}_{23} \mathrm{C}_{6}$ (fcc), yellow-Co (fcc), c) color legend for IPF $\mathrm{Z}$ coloring.

EBSD analyses showed that microstructures of the Ti6Al4V alloy contain small grains, which are mainly alpha hexagonal close-packed (hcp) Ti-type, and some small grains of beta Ti-(bcc) body-centred cubic structure (Figure 2). The microstructure of the Ti6Al7Nb alloy similarly contains small grains, the majority alpha (hcp)Ti with a small amount of Ti beta grains (bcc) structure, as shown in the EBSD analyses. Figure 5 shows Ti6Al4V EBSD mapping of phases a) band-contrast image, b) IPF $\mathrm{Z}$ direction. Figure 6 shows Ti6Al7Nb EBSD mapping of phases a) band-contrast image, b) IPF $\mathrm{Z}$ direction.

\subsection{AES analysis}

The Auger electron spectroscopy (FE-AES) instrument used in this study was a Thermo Scientific Microlab 310-F spectrometer, equipped with a thermally assisted Schottky field-emission electron gun (FEG) that provides a stable electron beam in the accelerating voltage range $0.5-25 \mathrm{kV}$, and a sphericalsector electron kinetic energy analyser. The spectra were usually acquired with a constant retarding ratio (CRR) of 4, which provides an energy resolution that is $0.5 \%$ of the pass energy. The parameters used in the AES analysis included a $10-\mathrm{keV}$ primary electron beam at a current of $1 \mathrm{nA}$, an angle of incidence of $0^{\circ}$, and an Auger emission angle of $30^{\circ}$. The AES depth profiling was performed by argon-ion sputtering at $3 \mathrm{keV}$ and scanning the ion beam over a $2 \mathrm{~mm} \times 2 \mathrm{~mm}$ area. The sputtering rate was about $0.7 \mathrm{~nm} / \mathrm{min}$.
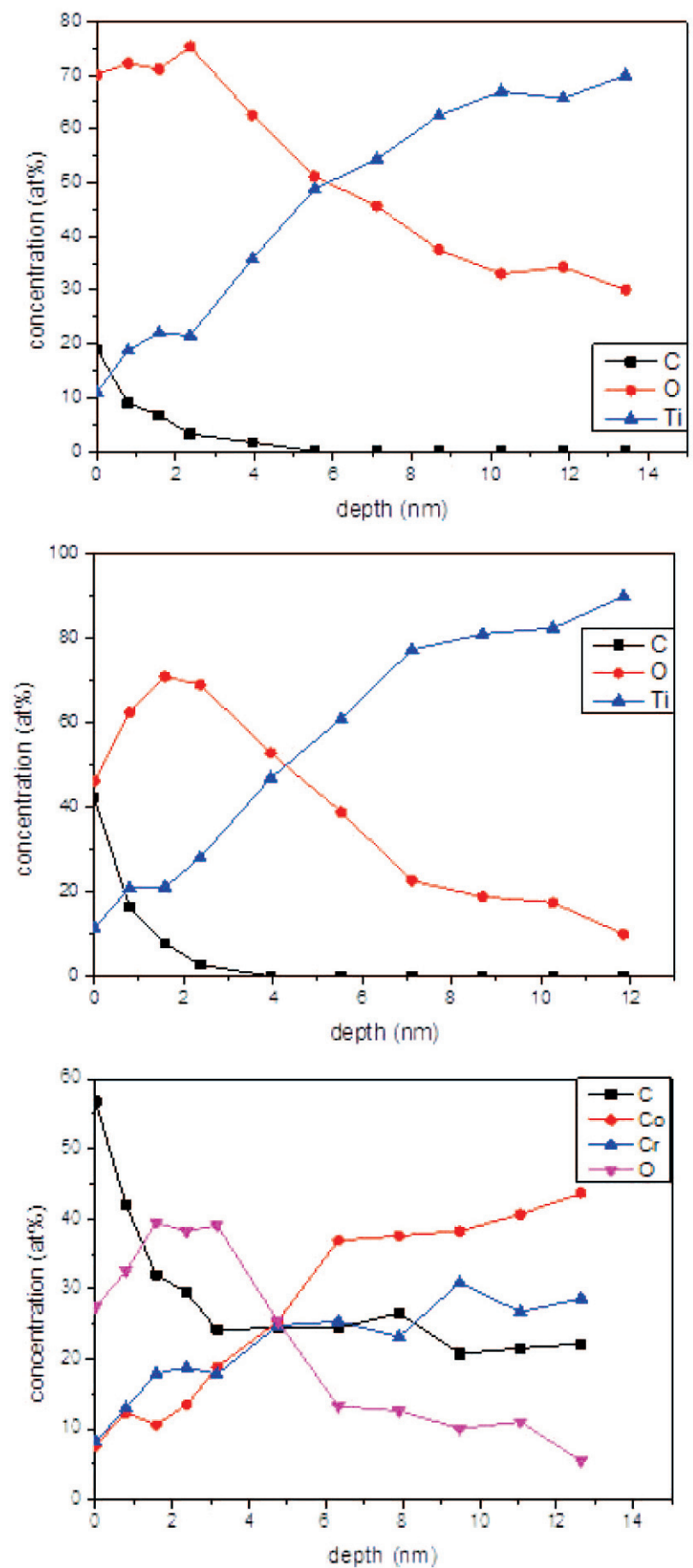

Figure 7: AES depth profiles of thin oxide films on: a) Ti6Al4V, b) Ti6Al7Nb, c) CoCrMo alloy 
The thin oxide films on the surfaces of the CoCrMo and Ti6Al4V, Ti6Al7Nb alloys were analysed by AES. The thicknesses of the thin oxide films on the Ti6Al4V and $\mathrm{Ti} 6 \mathrm{Al} 7 \mathrm{Nb}$ (primarily of $\mathrm{TiO}_{2}$ ) were estimated using AES depth profiling. Ti, O and $\mathrm{C}$ Auger peaks were detected in the AES analysis. Figure 7a shows the AES depth profile through the thin oxide film on the Ti6Al4V alloy. The estimated oxide thickness was about $7 \mathrm{~nm}$, consisting primarily of $\mathrm{TiO}_{2}$. The amount of $\mathrm{Al}_{2} \mathrm{O}_{3}$ is below the detection limit $(<0.1 \%$ of mass fractions), and no $\mathrm{V}$ was detected on the surface. Figure $\mathbf{7 b}$ shows the AES depth profile of the thin oxide film on the Ti6Al7Nb with an estimated thickness of $5 \mathrm{~nm}$, primarily of $\mathrm{TiO}_{2}$ with the small amounts of $\mathrm{Al}_{2} \mathrm{O}_{3}$ and $\mathrm{Nb}$ oxides being below the detection limit. Figure 7c shows the AES depth profile of a thin oxide film on the CoCrMo alloy. The estimated thickness of this thin oxide film, primarily a mixture of $\mathrm{Cr}_{2} \mathrm{O}_{3}$ and $\mathrm{Co}$ oxides, was found to be about $2 \mathrm{~nm}$.

\subsection{Conclusions of preliminary research}

The present study established the surface microstructures of biomaterials for hip and knee endoprostheses, Ti alloys and CoCrMo alloys. Stable and adherent thin oxide films protect the Ti alloys from intergranular and crevice corrosion attack and provide excellent biocompatibility and osteointegration of Ti alloys. The microstructures and mechanical properties of the Ti6Al4V alloys are very dependent on their thermomechanical processing treatments, especially homogenization heat treatments. The AES results showed that thin oxide films on: a) Ti6Al4V are primarily a mixture of $\mathrm{TiO}_{2}$ with a small amount of $\mathrm{Al}_{2} \mathrm{O}_{3}$, while the $\mathrm{V}$ is depleted the estimated thickness is $6 \mathrm{~nm}, \mathrm{~b}$ ) Ti6Al7Nb is primarily a mixture of $\mathrm{TiO}_{2}$ with a small amount of $\mathrm{Al}_{2} \mathrm{O}_{3}$ and $\mathrm{Nb}_{2} \mathrm{O}_{5}$ of estimated thickness $5 \mathrm{~nm}$ and c) CoCrMo is a mixture of $\mathrm{Co}$ and $\mathrm{Cr}$ oxides, primarily of $\mathrm{Cr}_{2} \mathrm{O}_{3}$ with small amounts of $\mathrm{Co}_{3} \mathrm{O}_{4}$ and $\mathrm{MoO}_{\mathrm{x}}$, thickness was estimated to be $2 \mathrm{~nm}$. We need to keep an optimal microstructure regarding corrosion and mechanical properties, which can be controlled through processing parameters and be standardized in the near future. The physical and chemical processes on the surface will be studied in detail to prevent the adhesion of bacteria and formation of biofilm to determine the implants' longevity.

\section{CONCLUSIONS}

The implantation of an artificial hip or knee is one of the most successful surgical procedure in orthopaedic surgery. With further research, including the analysis of the surface of biocompatible materials, monitoring novelties and carefully and selectively integrating them into everyday clinical practice, we want to improve the performance of these interventions.

\section{Acknowledgement}

This research was financially supported by the Tertiary project of the University Medical Center Ljubljana UKCLJ20160146 and by Slovenian Research Agency ARRS-0206-0132. Authors acknowledge A/Prof. Dr. Igor Belič for valuable discussions.

\section{REFERENCES}

${ }^{1}$ F. M. Azar, S. T. Canale, J. H. Beaty, Campbel's Operative Orthopaedics $-13^{\text {th }}$ edition, Elsevier 2016, Chapter; Arthroplasty of the knee, 396-469; Chapter; Arthroplasty of the hip, 166-337

${ }^{2}$ J. Raphel, R. M. Holodny, S. B. Goodman, S. C. Heilshorn, Multifunctional coatings to Simultaneously promote osseointegration and prevent infection of orthopaedic implants, Biomaterials, 84 (2016), 301-314, doi:10.1016/j.biomaterials.2016.01.016

${ }^{3}$ P. F. Sharkey, P. M. Lichstein, C. Shen, A. T. Tokarski, J. Parvizi, Why are Total Knee Arthroplasties failing today - Has anything changed after 10 years, The Journal of Arthroplasty, 29 (2014), 1774-78, doi:10.1016/j.arth.2013.07.024

${ }^{4}$ A. G. Gristina, Biomaterial-centered infection: microbial adhesion versus tissue integration, Science, 237 (1987), 1588-1595

${ }^{5}$ J. Charnley, Low Friction Arthroplasty of the Hip: Theory and Practice, Springer, Berlin, 1979

${ }^{6}$ J.Charnley, Anchorage of the femoral head prosthesis to the shaft of the femur. J. Bone Joint Surg, 42-B (1960), 28-30

${ }^{7}$ D. J. Berry, W. S. Harmsen, M. E. Cabanela, B. F. Morrey, Twentyfive-year survivorship of two thousand consecutive primary Charnley total hip replacements: factors affecting survivorship of acetabular and femoral components. J. Bone Joint Surg, 84 (2002), 171-177

${ }^{8}$ A. Sedrakyan, S. L. Normand, S. Dabic et al., Comparative assessment of implantable hip devices with different bearing surfaces: systematic appraisal of evidence, BMJ 343 (2011), 7434, doi:10.1136/bmj.d7434

${ }^{9}$ A. Gigante, C. Bottegoni, V. Ragone, L. Banci: Effectiveness of Vitamin-E-Doped Polyethylene in Joint Replacement: A Literature Review, J Funct Biomater, 6 (2015), 889-900, doi:10.3390/ jfb6030889

${ }^{10}$ J. A. D'Antonio, K.Sutton: Ceramic Materials as Bearing Surfaces for Total Hip Arthroplasty. Journal of the American Academy of Orthopaedic Surgeons, 17 (2009), 63-68

${ }^{11}$ T. Tateiwa, I. C. Clarke, P. A. Williams, J. Garino, M. Manaka, T. Shishido, K. Yamamoto, K. Imakiire, Ceramic total hip arthroplasty in the United States: safety and risk issues revisited, Am J. Orthop (Belle Mead NJ), 37 (2008), E26-31

${ }^{12}$ A. Shirazi-Adl, M. Dammak, G. Paiement: Experimental determination of friction characteristics at the trabecular bone/porous-coated metal interface in cementless implants. Journal of Biomedical Materials Research, 27 (1992), 167-175

${ }^{13}$ R. M. Meneghini, D. G. Lewallen, A. D.Hanssen: Use of porous tantalum metaphyseal cones for severe tibial bone loss during revision total knee replacement, J. Bone Joint Surg Am, 90 (2008) 78-84, doi:10.2106/JBJS.F.01495

${ }^{14}$ D. Zajonz, U. Birke, M. Ghanem et al., Silver-coated modular Mega endoprostheses in salvage revision arthroplasty after periimplant infection with extensive bone loss - a pilot study of 34 patients, BMC Musculoskeletal Disord 18 (2017)383, doi:10.1186/s12891017-1742-7

${ }^{15}$ F. D. Puccio, L. Mattei: Biotribology of artificial hip joints, World Journal of Orthopaedics

${ }^{16}$ D. Fabi, B. Levine, W. Paprosky et al.: Metal on Metal Total Hip Arthroplasty: Causes and High Incidence of early failure, Orthopaedics, 35 (2012),1009-1016, doi:10.3928/01477447-20120621-12 


\section{DOLINAR et al.: BIOMATERIALS IN ENDOPROSTHETICS}

${ }^{17}$ D. F. Dalury: Cementless total knee arthroplasty, current concepts review, J. Bone Joint 98 (2016), B867-873, doi:10.1302/0301620X.98B7.37367

${ }^{18}$ J. Lonner, C.Deirmengian: What's New in Adult Reconstructive Knee Surgery, J. Bone Joint Surg Am. 89 (2007) 2828-2837, doi:10.2106/JBJS.H.01106

${ }^{19}$ M. Jenko, M. Gorenšek, M.Godec, M. Hodnik, B. Šetina Batič, C. Donik, J. T. Grant, D. Dolinar, Applied Surface Science 427 (2018), 584-593, doi:10.1016/j.apsusc.2017.08.007 